\title{
POSSIBILITIES OF OBTAINING RENEWABLE ENERGY IN DAIRY FARMING ${ }^{1}$
}

\author{
Kinga Borek ${ }^{\mathrm{a}^{*}}$, Wacław Romaniuk ${ }^{\mathrm{b}}$ \\ a Institute of Technology and Life Sciences in Warsaw, Department of Rural Technical Infrastructure \\ Systems, Poland, e-mail: k.borek@itp.edu.pl, ORCID 0000-0002-0171-7498 \\ b Institute of Technology and Life Sciences in Warsaw, Department of Rural Technical Infrastructure \\ Systems, Poland, e-mail: w.romaniuk@itp.edu.pl, ORCID 0000-0001-7776-9940
}

*Corresponding author: e-mail: k.borek@itp.edu.pl

\begin{tabular}{|c|c|}
\hline ARTICLE INFO & ABSTRACT \\
\hline $\begin{array}{l}\text { Article history: } \\
\text { Received: May } 2020 \\
\text { Received in the revised form: } \\
\text { June } 2020 \\
\text { Accepted: June } 2020\end{array}$ & $\begin{array}{l}\text { Modern livestock facilities necessary in the production of milk, meat or } \\
\text { other animal products should be constructed with environmental pro- } \\
\text { tection in mind, while ensuring high quality of production and animal } \\
\text { welfare. The high level of mechanization in modern dairy farms, in- } \\
\text { cluding automated and robotic processes, allows obtaining high quality }\end{array}$ \\
\hline $\begin{array}{l}\text { Key words: } \\
\text { heat recovery, } \\
\text { milk, } \\
\text { photovoltaic panels, } \\
\text { methane fermentation, } \\
\text { natural fertilizer, } \\
\text { biogas }\end{array}$ & $\begin{array}{l}\text { raw material (e.g. milk), and significantly increasing labor and produc- } \\
\text { tion efficiency. In addition, the use of photovoltaic (PV) panels, heat } \\
\text { recovery from milk and obtaining biogas from the manure fermentation } \\
\text { process, contributes to large energy savings on the farm. Excess of nat- } \\
\text { ural fertilizers, which are an animal byproduct, can be used as a sub- } \\
\text { strate for methane fermentation. The presented examples of obtaining } \\
\text { renewable energy allow improving the economic efficiency of animal } \\
\text { production. They also ensure appropriate environmental conditions } \\
\text { through the innovative management of natural fertilizers. }\end{array}$ \\
\hline
\end{tabular}

\section{Introduction}

Modern animal production systems, used in functional livestock buildings equipped with modern devices and machines, ensure high quality of the obtained raw material and animal welfare.

The high level of mechanization of production operations and shaping the quality of production requires high energy consumption, especially electric power (Bisaglia et al., 2012). Currently, great attention is paid in R\&D studies to minimizing the use of conventional energy through the use of, e.g. solar energy, or heat recovery from production processes, e.g.

\footnotetext{
1 The publication of this study is supported through the project entitled: "Interdisciplinary research on improving energy efficiency and increasing the share of renewable energy sources in the energy balance of Polish agriculture", agreement no BIOSTRATEG1/269056/5/NCBR/2015 11.08.2015 r. financed by the National Center for Research and Development as part of the program BIOSTRATEG1.
} 
Milk. The studies focus also on obtaining energy in the form of biogas as a result of methane fermentation of manure (Michalska et al., 2013).

Solar power generates energy from a renewable source: sunlight. PV panels used to produce electric power are environmentally friendly and noise-free. Depending on the available possibilities, the panels can be mounted, e.g. on the roof, or on the ground, and their size can be adapted to the specific energy needs (Cukrowski, 2017; Michalska et al., 2013).

The use of heat from the technological process of cooling milk is one of the elements of reducing fuel consumption. It contributes to the improvement of the natural environment, e.g. by $\mathrm{CO}_{2}$ reduction. Recovery of heat energy received from chilled milk can be used to prepare domestic hot water. It can then be used in the livestock building, or in the household, either for production purposes, or to maintain hygiene or to prepare meals (Borowski, 2019; Pineda Quijano et al., 2017; Olkowski et al., 2013; Szulc and Myczko, 2010).

Biogas production is a good method of managing organic waste or natural fertilizers. Biogas, produced as a result of methane fermentation in landfills or biogas plants, can be used for the production of electric and heat power. It can also be treated and compressed, to be used as transport fuel (Putmai et al., 2020; Zapałowska and Gacek, 2019; Sikora and Tomal, 2016; Bacenetti et al., 2015; Bond and Templeton, 2011).

The main purpose of the work was to analyze the opportunities of obtaining renewable energy in animal production, especially in dairy farming. The studied renewable energy sources were heat recovered from milk cooling, solar power from roof-mounted PV panels and biogas from methane fermentation of manure, along with its transportation, depending on the needs of different users.

The possibility of using renewable energy in exemplary livestock buildings - the use of renewable energy sources in livestock buildings (Figures 1 and 2) using heat exchangers

A heat exchanger is a device that exchanges heat between a heating medium with a higher temperature and a heated medium with a lower temperature. In the co-current exchanger, the heating medium flows in the same direction as the heated medium. A counter-current exchanger is one in which the heating medium flows through the exchanger in the opposite direction to the heated medium. Co- and counter-current heat exchangers are flow-through heat exchangers.

Counter-current heat exchangers are smaller than co-current heat exchangers at the same heat output. The latest generation of capacitive heat exchangers is stratified storage tanks, which are hot water tanks without a coil. This tank is connected to a plate heat exchanger, which is to heat the water in the stratified tank.

Thanks to the new design and change in the method of heating water, stratified tanks are half the size of traditional storage heaters, and the time of heating water is also shorter.

Plate heat exchangers are characterized by a very intense heat exchange between the heating medium and the heated one. They are water-water, flow-through exchangers, usually working as counter-current exchangers. They are made of copper or stainless steel plates, bolted or soldered. They are characterized by a high heat transfer coefficient, small dimensions at high thermal outputs, high resistance to pressure and temperature changes, simple and easy installation (Zhang et al., 2018; Pineda Quijano et al., 2017; Olkowski et al., 2013; Szulc and Myczko, 2010; Kupczyk et al., 2001). 

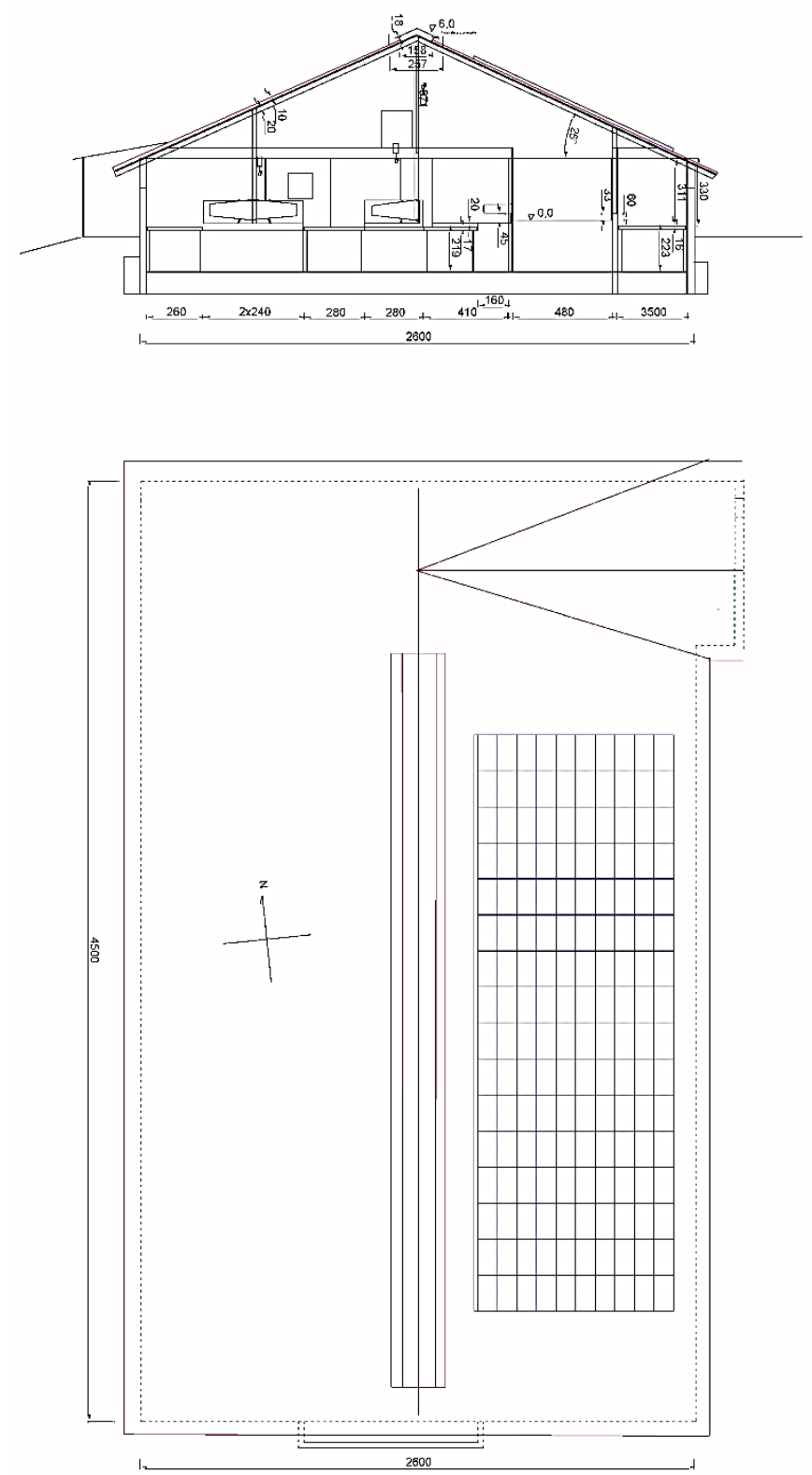

Figure 1. Layout diagram of PV panels on a loose housing, box stall livestock builing: $P V$ area $-2704 \mathrm{~m}^{2 ;}-10$ rows $x 16$ panels $=160$ pcs.; -160 pcs $x 255 \mathrm{~W}=40.8 \mathrm{~kW} ;-$ Technology - crystalline silicon; - Installed power - $40 \mathrm{~kW}$; - Roof slope $25^{\circ}$ 
Kinga Borek, Wacław Romaniuk

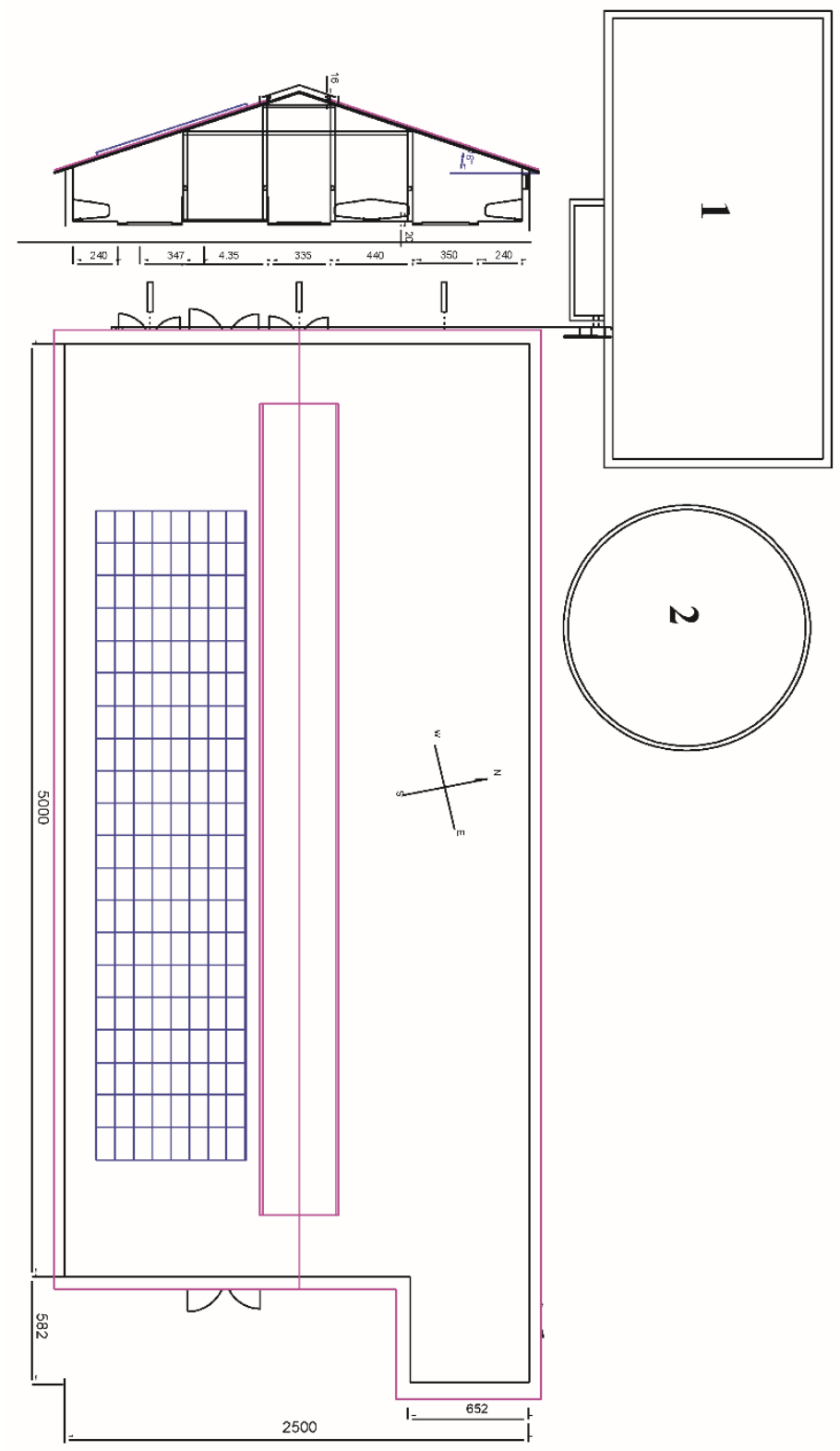

Figure 2. Illustrative layout diagram of the PV panels in a loose housing, box stall livestock building; 1 -solid manure pit, 2 -liquid manure tank: $-P V$ area $-2700 \mathrm{~m}^{2} ;-8$ rows $x 20$ panels $=160$ pcs. $;-160$ pcs $x 255 \mathrm{~W}=40.8 \mathrm{~kW} ;-$ Technology $\quad$ crystalline silicon; - Installed power - $40 \mathrm{~kW}$; - Roof slope: $18-20^{\circ}$

Source: a study by ITP 
Possibilities of obtaining...

\section{Exemplary solution of heat recovery from milk cooling}

Based on the research of the Institut de I'Elevage (The French Livestock Institute), the sample annual power consumption in dairy farming was minimum $160.00 \mathrm{kWh} \cdot \mathrm{LU}^{-1}, 420.00$ $\mathrm{kWh} \cdot \mathrm{LU}^{-1}$ on average, and maximum, $920.00 \mathrm{kWh} \cdot \mathrm{LU}^{-1}$. Calculated per liter of milk, it was respectively: minimum $27.00 \mathrm{Wh}, 61.00 \mathrm{Wh}$ on average and maximum $120.00 \mathrm{Wh}$ (Paulais et al., 2011). The energy savings are shown in Table 1.

Table 1.

Energy savings in heat recovery from milk cooling

\begin{tabular}{lr}
\hline $\begin{array}{l}\text { Electric power consumption of the } 350,0001 \text { milk } \\
\text { capacity cooler tank }\left(27 \mathrm{Wh} \cdot 11 \text { of milk }{ }^{-1}\right)\end{array}$ & $9450 \mathrm{kWh}$ \\
\hline Savings: $50 \%$ energy consumption per tank & $4725 \mathrm{kWh}$ \\
\hline Return on investment costs & 9 years \\
\hline
\end{tabular}

Source: Paulais et al. (2011)

\section{Heat recovery during the milk cooling}

a) Calculation of the amount of heat available for recovery in cooling milk from one cow in one year

- The milk temperature after milking is $+38^{\circ} \mathrm{C}$.

- According to the standards, milk must be cooled to $+4^{\circ} \mathrm{C}$ in no later than 4 hours.

Determination of specific heat of milk at a temperature of $+38^{\circ} \mathrm{C}\left(311^{\circ} \mathrm{K}\right)$ :

$$
\mathrm{Cml}=444+609,56 \ln 311=3943 \mathrm{~J} \cdot \mathrm{kg}^{-1} \cdot{ }^{\circ} \mathrm{K}^{-1}=3,943 \mathrm{~kJ} \cdot \mathrm{kg}^{-1} \cdot{ }^{\circ} \mathrm{K}^{-1}
$$

Determination of milk density:

$$
\begin{aligned}
\xi \mathrm{ml}= & 1166-0.45 \mathrm{~T}-1.46 \mathrm{f} \mathrm{T}+321.6 \mathrm{f}=1166-0.45311 \\
& -1.460 .04311+321.60 .04=1021 \mathrm{~kg} \cdot \mathrm{m}^{-3}
\end{aligned}
$$

where:

$\mathrm{Cml}$ - specific heat of milk $\left(\mathrm{kJ} \cdot \mathrm{kg}^{-1} \cdot{ }^{\circ} \mathrm{K}^{-1}\right)$

$\xi \mathrm{ml}-$ milk density $\left(\mathrm{kg} \cdot \mathrm{m}^{-3}\right)$

$\mathrm{T} \quad$ - milk temperature $\left({ }^{\circ} \mathrm{C}\right)$

f $\quad$ milk fat content.

Determination of the amount of heat recovered in the milk cooling process from one cow per day:

$$
\mathrm{Qd}=\mathrm{C} \mathrm{ml} \cdot \mathrm{md} \cdot \mathrm{t}(\mathrm{kWh})
$$

where:

md - mass of milk obtained from one cow $(\mathrm{kg})$ per day,

$\mathrm{t} \quad$ - temperature difference between freshly milked and chilled milk.

Assuming that one cow will produce milk at $\mathrm{Vd}=0.016 \mathrm{~m}^{3}$ per day, the mass of milk per cow per day will be:

$$
\mathrm{md}=\mathrm{Vd} \cdot \xi \mathrm{ml}=0.161021=16.3 \mathrm{~kg}
$$


The recovered amount of heat per day per cow will be:

$$
\mathrm{Qd}=3.943 \cdot 16.3 \cdot 34=2185 \mathrm{~kJ}=0.607 \mathrm{kWh}
$$

The annual amount of heat recovered in cooling milk from one cow will be:

$$
\mathrm{Qr}=\mathrm{Qd} 365=221.5 \mathrm{kWh}
$$

\section{b) Heat recovery from milk cooling}

For example, if there are 70 cows in a building, milked with a single-unit milking robot, the amount of heat recovered from milk per day will be $152950 \mathrm{~kJ}$, which is equivalent to $42.49 \mathrm{kWh}$ of electric power. The annual heat recovery from milk cooling in this building will be $55,826,750 \mathrm{MJ}$, which is $15508.85 \mathrm{kWh}$ of electric power.

In a barn with 144 cows milked in a double-unit, eight-stand milking parlor, the daily heat recovery from milk cooling will be $314640 \mathrm{~kJ}$, i.e. is $87.408 \mathrm{kWh}$ of elecric power. Annual heat recovery during the milk cooling in this building will be $114,843.60 \mathrm{MJ}$, which is equivalent to $31,903.92 \mathrm{kWh}$ of electric power.

\section{Installation of phtovoltaic panels on the roofs of livestock buildings}

Photovoltaic (PV) panels will be installed on the more favorable sides of the roofs, where the sun operates the longest during the day. A view of the panels installed on the roofs of livestock buildings is shown in Figures 1 and 2, respectively. On the part of the roof with PV panels an appropriately painted anti-corrosive trapezoidal sheet must be used for roofing.

- Dimensions of a single panel: $100 \mathrm{~cm}$ in width $\mathrm{x} 169 \mathrm{~cm}$ in height

- Power obtained from a single PV panel: $255 \mathrm{~W}$

- Cost of installing a $1 \mathrm{~kW} \mathrm{PV} \mathrm{installation:} \mathrm{approx.} \mathrm{PLN} \mathrm{4,500}$

Technical and economic data on the PV installation on livestock building roofs are presented in Table 2.

Table 2 .

Technical and economic data on the PV installation on livestock building roofs (Fig. 1 and 2)

\begin{tabular}{cccccc}
\hline $\begin{array}{c}\text { Livestock } \\
\text { building }\end{array}$ & $\begin{array}{c}\text { Roof panel area } \\
\left(\mathrm{m}^{2}\right)\end{array}$ & $\begin{array}{c}\text { Panel power } \\
(\mathrm{kW})\end{array}$ & $\begin{array}{c}\text { Roof slope } \\
(\text { degrees })\end{array}$ & $\begin{array}{c}\text { Sunlight side of } \\
\text { the roof }\end{array}$ & $\begin{array}{c}\text { Total cost of } \\
\text { the PV } \\
\text { installation } \\
(\text { PLN })\end{array}$ \\
\hline 1 (in Fig. 1) & 2704 & 40.8 & 25 & eastern & 180,000 \\
\hline 2 (in Fig. 2) & 2704 & 40.8 & $18-20$ & southern & 180,000 \\
\hline
\end{tabular}

The total cost of the PV installation together with the control panel and accessories for the distribution of power for use in the livestock building and for sale to the external grid in both barns is PLN 180,000.

The user will be able to use the produced PV power at any time. When it is used up, the system will automatically switch to the external grid. 
Possibilities of obtaining...

\section{Efficiency of PV panels and the use of PV power in a livestock building}

The efficiency of monocrystalline silicon PV cells currently ranges between $14 \%$ and $17 \%$, and of multicrystalline cells, between $13 \%$ and $16 \%$ (Pławecki et al., 2019). There are also specially designed monocrystalline cells with a $20 \%$ efficiency. Unfortunately, due to the small scale of production and high manufacturing costs, they are much more expensive than classic monocrystalline cells, at 14-17\% efficiency (Zapałowicz, 2019).

The efficiency of the cell decreases with an increase in temperature - this can be minimized with good ventilation. Without ventilation, losses are 5\% lower than with ventilation. At high temperatures, a $0.5 \%$ reduction in efficiency per $1{ }^{\circ} \mathrm{C}$ can be assumed. According to research, if the cell temperature increases from $25^{\circ} \mathrm{C}$ to $55^{\circ} \mathrm{C}$, the efficiency will decrease by approx. $15 \%$.

The rated electric power of $\mathrm{PV}$ cells is given for a temperature of $25^{\circ} \mathrm{C}$. Typical PV panels usually operate at a temperature of $55-75^{\circ} \mathrm{C}$, which results in a decrease in power generation by $12-25 \%$ of the rated power value.

At just $50 \%$ of sunny days a year, if average annual single demand for electric power is approx. $3.5 \mathrm{~kW}$, then with the total power of the PV system at $40.8 \mathrm{~kW}$, the power supply for the livestock building will reach approx. 50\% (Pławecki et al., 2019; Zapałowicz, 2019).

\section{Innovative solutions for obtaining biogas from substrates above $20 \%$ dry matter}

The characteristics of the technology for obtaining biogas from the leached organic manure fraction is subject to Patent Application No. P.421062 of 30.03.2017.

The method of biogas production and the necessary assembly are presented in detail in Figure 3. Following a necessary adaptation, this technology can also be used in other animal production farms.

The purpose of the presented innovative solution, pending patent, is the production of biogas from manure and determining a necessary assembly, taking into account the process of manure processing, to obtain a solid fraction, suitable for reuse as litter or as a raw material for compost and a liquid fraction for use as a natural fertilizer for feeding plant crops, in addition to gas. The project allows achieving two main goals. The first is management of natural manure in the solid form while maintaining good agricultural practices, i.e. preventing contamination of groundwater. The second goal is gas production to meet the energy demand of the farm.

The invention's design is presented in Figure 3 (vertical section). The livestock building 1 was designed to be technologically connected to the solid manure pit 2 , in which manure 3 is collected, loaded with a loader 4 (coupled with a tractor) into containers 5. During collection in the manure pit, as well as during loading into the container 5 , the liquid manure 3 is gravity drained into the preliminary tank 6 , located below the loading surface.

The biogas production unit is a silo flushing chamber 7 , divided into hermetically sealed sectors 8 , in which containers 5 filled with manure 3 are placed and kept hermetically sealed for approx. 30 days. The containers 5 have openwork floors. In the floor of each of the sectors 8 of the silo chamber 7, there is a drain 9, connected to a drain pipe 10 directed to the organic fraction tank 11, in which the organic fraction accumulates after rinsing the solid manure 3 placed in containers 5 in the silo flushing chamber 7 .

Above, in each sector 8 of the silo rinsing chamber 7, sprinkler nozzles 12 are installed, through which the liquid manure is supplied for washing out the solid manure 3 . The organic 
fraction drained off from the solid manure 3 along with solid elements $s$ is directed through a discharge line 10 to the organic fraction tank 11 .

The organic fraction tank 11 is connected to the biogas plant fermentation chamber 13 with a pipe 14, at the end of which, in the organic fraction tank 11, a pump 15 is mounted. It pumps the organic fraction into the fermentation chamber 13, where this fraction is fermented.

Biogas, which is a product of methane fermentation, is discharged into the biogas tank via a pipe. The biogas is also produced as a result of manure fermentation 3 taking place in the silo washing chamber 7. It is discharged from each sector 8 through a pipe. After dehydration and desulphurisation, it is pressure-pumped into the tank.

In the side wall of the fermentation chamber 13 tubular containers 17 are mounted, filled with expanded clay, which is a source of methane bacteria, stimulating the fermentation. An important element of the fermentation chamber 13 is the PV collector 18, powering the heaters 19, mounted inside the fermentation chamber 13. A drain pipe 20 is directed from the side wall of the fermentation chamber 13 to the expansion tank 21 , enabling gravity drainage of the fermented substrate from the fermentation chamber 13 and maintaining a constant level of the substrate in the fermentation chamber 13. The fermented substrate collected in the expansion tank 21 is fed through a separator drain 22 to the separator 23 via a pump 15 installed in the tank. In the separator 23 , solid fractions are separated from the liquid fractions. As a separated mass, the solid fraction is discharged to the heap in the form of a compost plate 24 , and then used for animal bedding or compost. On the other hand, the liquid fraction is gravitationally discharged as liquid manure into the final tank 25 connected to the separator 23. This tank has an installed pump 26, which pumps the separated liquid manure through pipe 27 to the sprinkler nozzles 12 installed in the upper walls of the silo flushing chamber 7 , for flushing manure 3 accumulated in containers 5 . A control valve 28 is mounted on the liquid manure pipe 27 to direct the liquid manure stream to the relevant sector 8 . Excess liquid manure is directed to the storage tank via a pipe 29.

An agitator 31, axially mounted in the fermentation chamber 13 , is to ensure homogenization of the mass and its uniform fermentation. Another element of the assembly is a screw conveyor 32 , which adds the energy plant substrate to the fermentation chamber 13 , usually raw crushed corn or corn silage, or grass. Biogas produced as a result of fermentation should be dehydrated and desulphurized. The biogas thus cleaned is then pumped into the storage tank 16 . The next stage is the transmission of biogas (biomethane) via pipeline 32 to a cogeneration unit, where biogas will be converted into heat and electric power (Romaniuk et al., 2017a).

\section{An example installation for compressing, transporting and distributing biogas for animal production}

Figure 4 shows the biogas compression, transport and distribution system used in the farm located in Jaworze, a part of the Experimental Station of National Research Institute of Animal Production in Grodziec Śląski (Romaniuk et al., 2017b).

The installation's design and prototyping was carried out by the team of the Institute of Technology and Life Sciences, in cooperation with NGV Autogas Sp. z o.o. The concept of the above-mentioned system (Fig. 4) consists of the following technological units: a biogas purification module fed from a biogas tank, a compressor, containers (high pressure cylinders) for storing compressed biogas, placed on a transport trailer, a biogas expansion and 
extraction station to supply the animal production energy demand, and a reducing valve allowing biogas transportation to power energy receivers.

The view of the biogas refueling and compression station is shown in Figure 5, along with a brief technical description of the compressor.
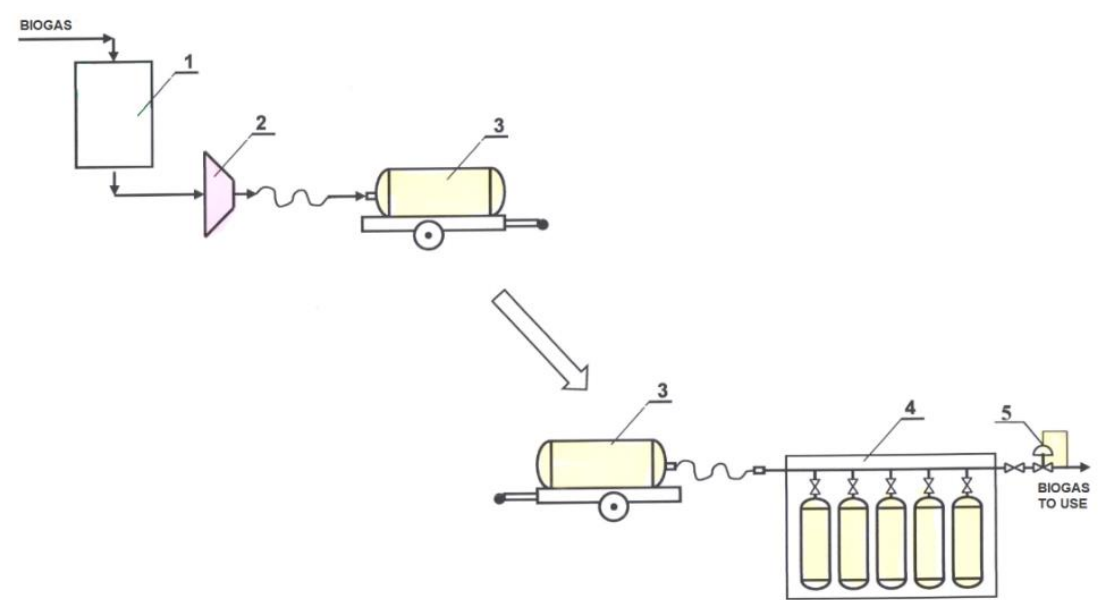

Figure 4. A transport and distribution unit for small amounts of biogas, Patent No. 232201 of 13.06.2017.: 1 - purification unit for biogas fed from the biogas tank; 2 - compressor; 3 - containers (high pressure cylinders) for storing compressed biogas, placed on a transport trailer; 4 - biogas expansion and extraction station to supply animal production energy demand; 5 - reducing valve to enable biogas transport to power energy receivers

Source: own study
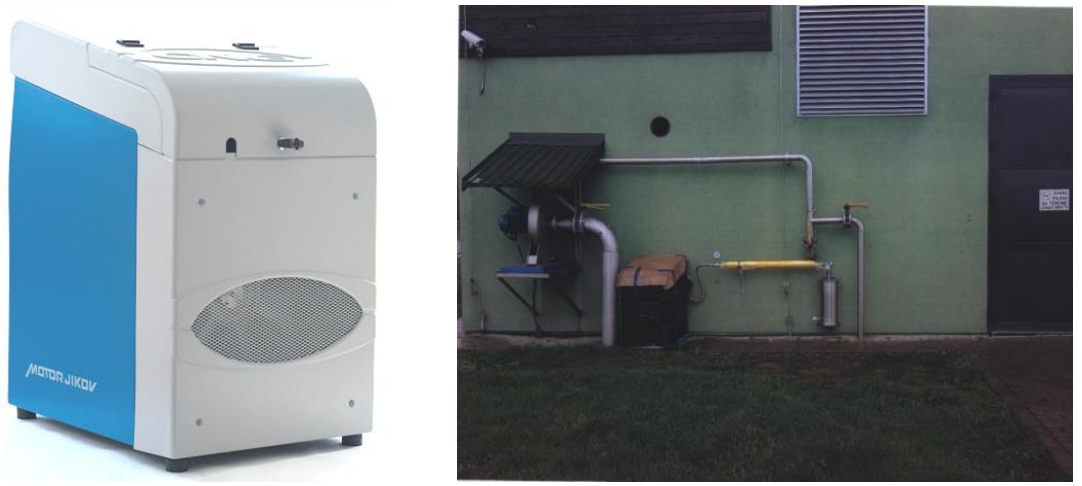

Figure 5. View of the gas installation in the gas compression station. Gas compressor with maximum power consumption of $2.5 \mathrm{~kW}$ and a rated capacity of $5 \mathrm{~m}^{3} / \mathrm{h}$ (at $15^{\circ} \mathrm{C}$ and $200 \mathrm{bar}$, with an inlet gas pressure of 0.1 bar)

Source: own materials and obtained from the company NGV Autogas Sp. zo.o 
The view of the connected cylinders with the reducing valve, supplying biogas receivers is shown in Figure 6.

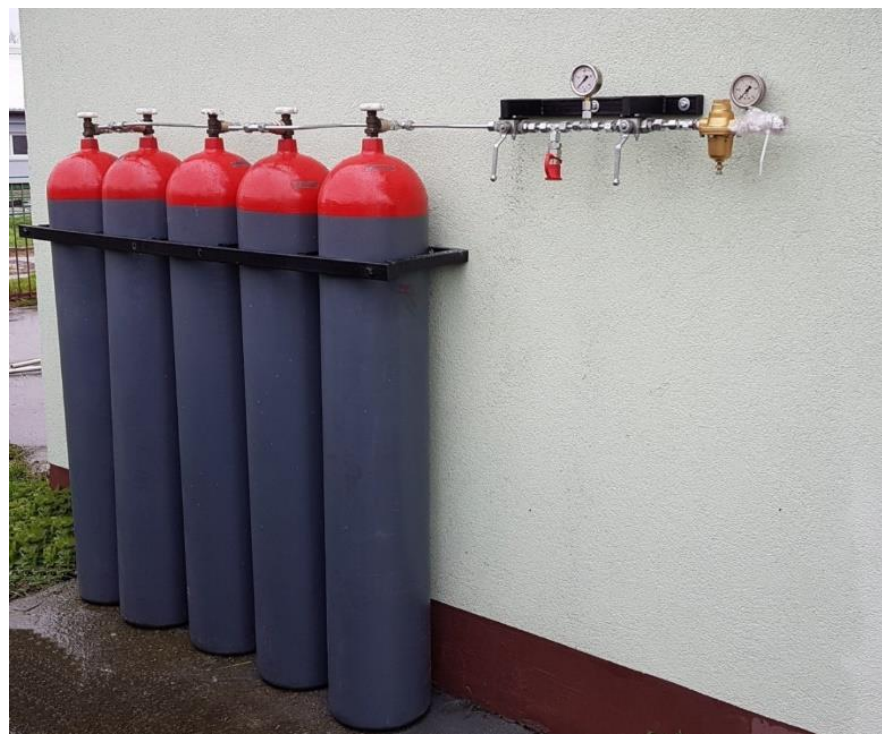

Figure 6. View of the cylinder connection to the biogas supply

Source: own materials

The transport trailer with loaded biogas cylinders is shown in Figure 7.
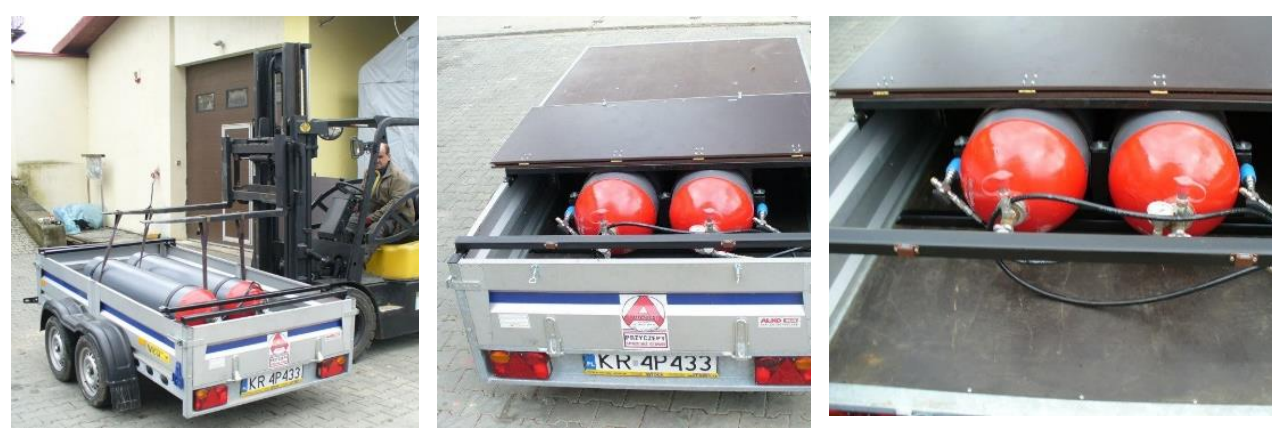

Figure 7. View of the transport trailer with biomethane cylinders, secured on the trailer.

Source: own materials 


\section{Summary}

Modern livestock facilities necessary in the production of milk, meat or other animal products should be constructed with environmental protection in mind, while ensuring high quality of production and animal welfare. The development of specialized animal production farms is mainly restricted by:

- Environmental emissions, incl. $\mathrm{CO}_{2}, \mathrm{NH}_{3}, \mathrm{CH}_{4}, \mathrm{NO}_{\mathrm{x}}, \mathrm{H}_{2} \mathrm{~S}$, groundwater and soil contamination, dust and noise levels

- Production safety-related reasons, including animal welfare, human safety and userfriendliness, quality of the produced raw material

- The economics, including price stability for agricultural products, energy raw material and power prices.

The presented examples of obtaining renewable energy allow improving the economic efficiency of animal production. They also ensure appropriate environmental conditions through the innovative management of natural fertilizers. Currently, much attention is paid to the use of renewable energy to improve environmental conditions in livestock buildings, as well as to minimize production costs. Obtaining energy from milk cooling, PV panels and biogas aims to improve them in the micro- and macro-scale. The technological possibilities of obtaining biogas from manure, as well as micro scale biogas transport techniques and technologies, using simple sets of devices, allow for local energy storage in the form of biogas.

\section{References}

Bacenetti, J., Negri, M., Lovarelli, D., Garcia, L.R., Fiala, M. (2015). Economic performances of anaerobic digestion plants: effect of maize silage energy density at increasing transport distances. Biomass and Bioenergy, 80, 73-84.

Bisaglia, C., Belle, Z., Van Den Berg, G., Johanna, C.A.M. Pompe. (2012). Automatic vs. conventional feedineg systems in robotic milking dairy farms: a survey in the Netherlands. Proceedings of AgEng 2012 International Conference on Agricultural Engineering (CIGR), Valencia - Spain, 1-7.

Bond, T., Templeton, M.R. (2011). History and future of domestic biogas plants in the developing world. Energy for Sustainable Development, 15, 347-354.

Borowski, K. (2019). Teoretyczny model ekoprzestrzeni w zastosowaniu do rewitalizacji obszarów wiejskich. Przeglad Budowlany, 9, 88-93.

Cukrowski, A. (2017). Fotowoltaika dla gospodarstw rolnych i małych przedsiębiorstw. Czysta Energia, 5-6, 13-15.

Kupczyk, W., Osiak, J., Wojciechowski, S. (2001). Pompy ciepła odpadowego w technologii produkcji surowego mleka. Technika Rolnicza, 50, 1, 14-16.

Michalska, K., Pazera, A., Bizukojć, M., Wolf, W., Sibiński, M. (2013). Innowacyjne mleczarnie niezależność energetyczna i technologie bezodpadowe konsekwencją inwestycji biogazowych i fotowoltaicznych. Acta Innovations, 9, 5-17.

Olkowski, T., Koniecko, A., Przybylski, Ł. (2013). Wykorzystanie ciepła odpadowego ze schładania mleka do ogrzewania wiejskiego budynku mieszkalnego. Inżynieria Rolnicza (Agricultural Engineering), 2(143), 1, 245-252.

Paulais, A.M., Roque, M., Gourreau, J.M., Le Chatelier, D. (2011). Le logement du troupeau laitier. Ed. France-Agricole, 352. 
Pineda Quijano, D., van der Pal, M., Ferreira, I.C., Boer, de, R., Vollenbroek, J. (2017). Heat recovery in milk powder drying by using a liquid sorption process. $12^{\text {th }}$ IEA Heat Pump Conference Stichting HPC 2017.

Putmai, N., Jarunglumler, T., Prommuak, C., Pavasant, P., Flood, A.E. (2020). Modelling of swine farm management for enhancement of biogas production and energy efficiency. IOP Conference Series: Materials Science and Engineering, 736.

Pławecki, M., Rówiński, E., Bzowski, B. (2019). Badania optymalizacji sprawności krystalicznych ogniw krzemowych w warunkach naturalnych i laboratoryjnych. Energetyka, 5, 367-369.

Romaniuk, W., Łochowski, B., Borek, K., Mazur, K. (2017a). Sposób wytwarzania biogazu i zespół urządzeń do realizacji tego sposobu. Patent application No. P.421062, submitted on 30. March 2017.

Romaniuk, W., Łochowski, B., Borek, K., Mazur, K., Wardal, W.J. (2017b). Układ do transportu i dystrybucji niewielkich ilości biogazu. Patent No. 232201, submitted on 13. June 2017.

Sikora, J., Tomal, A. (2016). Wyznaczenie potencjału energetycznego biogazu w wybranym gospodarstwie rolnym. Infrastruktura i Ekologia Terenów Wiejskich, III/2, 971-982.

Szulc, R.; Myczko, A. (2010). Wstępne schładzanie udojonego mleka a redukcja emisji dwutlenku węgla. Journal of Research and Applications in Agricultural Engineering, 55(2), 94-96.

Zapałowicz, Z. (2019). Ocena parametrów pracy instalacji fotowoltaicznej z modułami monokrystalicznymi po 20 latach jej eksploatacji. Rynek Energii, 4.

Zapałowska, A., Gacek, T. (2019). Ekonomiczne aspekty pozyskiwania i wykorzystania biogazu. Polish Journal for Sustainable Development, 23(2), 81-89.

Zhang, Y., Munir, M.T., Udugama, I., Yu, W., Young, B.R. (2018). Modelling of a milk powder falling film evaporator for predicting process trends and comparison of energy consumption. Journal of Food Engineering, 225, 26-33.

\title{
MOŻLIWOŚCI POZYSKANIA ENERGII ODNAWIALNEJ W CHOWIE BYDLA MLECZNEGO
}

\begin{abstract}
Streszczenie. Nowoczesne obiekty inwentarskie niezbędne w procesie produkcji mleka, mięsa lub innych produktów, powinny uwzględniać uwarunkowania związane z ochroną środowiska przy zapewnieniu wysokiej jakości produkcji oraz uwzględnieniu dobrostanu zwierząt. Wysoki poziom mechanizacji w nowoczesnych oborach krów mlecznych, w tym automatyzacja i robotyzacja, umożliwiają pozyskanie surowca (np. mleka) o wysokiej jakości, a także pozwalają na znaczący wzrost wydajności pracy i produkcji. Dodatkowo zastosowanie paneli fotowoltaicznych, odzysku ciepła z mleka oraz pozyskiwania biogazu z procesu fermentacji, przyczynia się do dużych oszczędności na energii w gospodarstwie. Nadmiar nawozów naturalnych, powstających w wyniku produkcji zwierzęcej, może być wykorzystywane jako substrat do fermentacji metanowej. Przedstawione w pracy przykłady pozyskania energii odnawialnej umożliwiają poprawienie efektywności ekonomicznej produkcji zwierzęcej, a także zapewnienie odpowiednich warunków środowiskowych przez innowacyjną gospodarkę nawozami naturalnymi.
\end{abstract}

Słowa kluczowe: odzysk ciepła, mleko, panele fotowoltaiczne, fermentacja metanowa, nawóz naturalny, biogaz 